\begin{tabular}{c} 
Volume and Issues Obtainable at Center for Sustainability Research and Consultancy \\
Journal of Business and Social Review in Emerging Economies \\
ISSN: 2519-089X (E): 2519-0326 \\
Volume 3: Issue 2December 2017 \\
CSRᄃ \\
Journal homepage: $\underline{\text { www.publishing.globalcsrc.org/jbsee }}$ \\
\hline
\end{tabular}

\title{
Combination of Microcredit and Micro-Training with Mediating Role of Formal Education: A Micro-Enterprise Success Formula
}

\author{
${ }^{1}$ Waseem-Ul-Hameed, ${ }^{2}$ Tanveer Hussain, ${ }^{3}$ Muhammad Azeem, ${ }^{4}$ Muhammad Farhan Basheer, ${ }^{5}$ Muhammad \\ Arif
}

${ }^{1} \mathrm{PhD}$ Scholar, School of Economics, Finance \& Banking, Universiti Utara Malaysia, Malaysia, expertwaseem@yahoo.com

${ }^{2} \mathrm{PhD}$ Scholar, School of Economics, Finance \& Banking, Universiti Utara Malaysia,

Malaysia,tanveer_icon@hotmail.com

${ }^{3} \mathrm{PhD}$ Scholar, School of Business Management, Universiti Utara Malaysia, Malaysia, azeeminpk@gmail.com

${ }^{4} \mathrm{PhD}$ Scholar, School of Economics, Finance \& Banking, Universiti Utara Malaysia, Malaysia, khwaja.farhan7@gmail.com

${ }^{5} \mathrm{M}$ Phil Scholar, National College of Business Administration \& Economics (NCBA\&E), Bahawalpur, Pakistan. khalifa.arif90@gmail.com

\begin{tabular}{l}
\hline ARTICLEDETAILS \\
\hline History \\
Revised format: Nov 2017 \\
AvailableOnline: Dec 2017 \\
\hline Keywords \\
Micro-enterprises, \\
microfinance, microecredit, \\
micro-training, education.
\end{tabular}

\section{JEL Classification:}

P36, P39

\begin{abstract}
Purpose: The purpose of this study is to develop a distinctive formula (framework) for micro-enterprise success. As the success of micro-enterprise is under debate from many decades, however, the researchers and entrepreneurs are unable to find the unique factor to develop a comprehensive framework.

Design/Methodology/Approach: The current study is based on conceptual framework. Prior studies are used to develop the framework and hypothesis. Moreover, conclusion is based on literature review.

Findings: It is investigated that, microfinance factors (i.e., micro-credit and micro-training) has a positive relationship with micro-enterprise success. However, among all other microfinance factors (i.e., micro-saving, microinsurance, social capital), micro-credit and micro-training haverelatively higher effect on microenterprise performance followed by a level of education. Moreover, it is found thateducation mediates the relation between microfinance factors and micro-enterprise success.

Implications/Originality/Value: This study contributed tothe body of knowledge by developing a micro-enterprise success formula for researchers and entrepreneurs, which ultimately improve the performance of microenterprises. Hence, the current study is beneficial for microfinance institutions and other practitioners to enhance micro-enterprise success.
\end{abstract}

(C) 2017 The authors, under a Creative Commons AttributionNonCommercial 4.0

Corresponding author's email address: expert_waseem@yahoo.com

Recommended citation:Hameed, W., Hussain, T., W, Azeem, M., Basheer, M. F. \&Arif, M.,(2017)Combination of Micro-Credit and Micro-Training with mediating role of Formal Education: A Micro-Enterprise Success Formula. Journal of Business and Social Review in Emerging Economies, 3(2) 285-291.

DOI:https://doi.org/10.26710/jbsee.v3i2.191 


\section{Introduction}

There is a genuine problem with the term "success", and it has different interpretations as well as perceptions in the small firm sector (Beaver, 2002, p. 98). The subject of micro-enterprise success is more popular among business researchers and entrepreneurs; eachwants to explore definitive formula for success (Beaver, 2002). Success is frequently viewed by profitability; however, it becomes more complicated when trying to explore different success factors. For the success of micro-enterprise, microfinance institutions provide financial and non-financial services. Financial services include credit, saving, insurance and payment services to eligible candidates (Ledgerwood, 2000). Microfinance institutions are also providing non-financial services (Robinson, 2001). These services include training and skill development programs for micro-enterprise success.

It is important to identify the measure of success which is still undefined, but there are some general factors which influence the business success (Alsbury, 2001). Previous research studies on the relationship of different success factors and small business success are missing by the comprehensiveframeworkand small business owners are aiming to find out the management strategies, personal characteristics and business objectives, linked most closely to small business success (Gadenne, 1998).

Additionally, suggested from literature, there is a need to study on credit, jointly with training on entrepreneurship in developing countries, as in low-income countries women lack educational level (Harrison \& Mason, 2007; Ibru, 2009; Peter, 2001; Tazul, 2007). It is suggested from the literature that training and credit should go together, it does not matter whether training is little or more (Ibru, 2009; Kuzilwa, 2005). According to the literature, without training, microcredit cannot be an effective tool for poverty alleviation (Adams \& Von Pischke, 1992; Imai, Arun, \&Annim, 2010). By taking microcredit from microfinance institutes, poor people start microenterprises, but they need training to run these microenterprises. As Bernard, Kevin and Khin (2016) described that poor people start microenterprises through microcredit and run efficiently by getting training. Therefore, a combination of micro-credit and micro-training is adopted in this study to develop a framework for micro-enterprise success. Hence, the framework of the currentstudy will follow the literature.

Nonetheless, micro-credit and micro-training are also not sufficient for small business success, but it also needs formal education for entrepreneurs. As mentioned, microcredit is not sufficient for success, but it also needs certain educational level (Atmadja, Su \& Sharma, 2016). Because education increases the performance of micro-enterprises (Copestake, Bhalotra, \& Johnson, 2001; Leach\&Sitaram, 2002) and micro-credit is an initial invested capital with has a positive linkage with venture survival (Cooper, Gimeno-Gascon, \& Woo, 1994). However, the literature shows that education has a mediating role among microfinance factor (e.g., micro-credit, micro-training) and micro-enterprise success. Literature indorses that training and education have a positive influence on enterprise performance (Akanji, 2006; Cheston \& Kuhn, 2002; Kuzilwa, 2005). Therefore, there is a significantrelationship between training and enterprise performance, education and enterprise performance. As competencies are not given by birth but through education (Lans, Hulsink, Baert, \& Mulder, 2008). That is why education is vital to better learn from training and proper use of microcredit. That is the reason, micro-credit and micro-training have a significant relation with education. Hence, according to the Baron and Kenny (1986), education could be used as a mediator between microfinance factors (i.e., micro-credit, micro-training) and micro-enterprise success.

As the subject of small business success is more popular among business researchers and entrepreneurs, each wants to explore definitive formula for success (Beaver, 2002), that is whymain objective of this research study is to develop a success formula (framework) for micro-enterprise success. To achieve the primary objective, study has also following sub-objectives:

1. Joint effect of micro-credit and micro-training on micro-enterprise success. 
2. Role of education to enhance the joint effect of micro-credit and micro-training on microenterprise success.

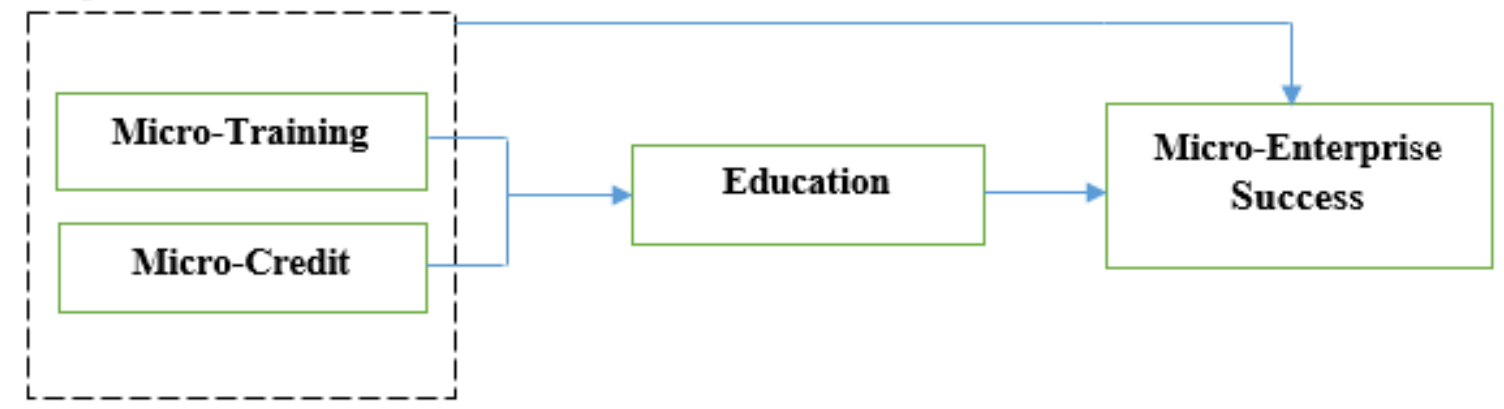

Figure. 1: Theoretical framework

\section{Literature Review and Hypotheses Development}

Microfinance institutions should provide entrepreneurial training prior to the provision of micro-credit to selected clients for extension or initiation of micro-enterprise because most of the clients initiated businesses, but they could not efficiently run due to lack of management skills (Naeem et al., 2015). Therefore, micro-credit itself is not enough for micro-enterprise success. Training is crucial for better utilization of micro-credit, and it is an essential factor for entrepreneurs to run micro-enterprise effectively. Meanwhile, education is also vital for problem-solving ability, decision making, and teamwork skills (Fuente \&Domenech, 2006; Magoutas et al., 2012; Switzer \& Huang, 2007). Hence, micro-enterprise success formula heavily based on micro-credit, micro-training, and education.

\subsection{Education and Micro-Enterprise Success}

In the advanced competitive business environment, innovation and specialized knowledge playing a vital role towards growth and competitive edge (Mamun, 2016). Therefore, new knowledge creation through innovative methods implementation creates competitive advantage (Magoutas, Papadogonas\&Sfakianakis, 2012). But the role of education is much crucial, as education is an important factor for innovation and research. Meanwhile, specialized knowledge improves problem-solving ability, decision making, and teamwork skills (Fuente \&Domenech, 2006; Magoutas et al., 2012; Switzer \& Huang, 2007).

More specifically, education is a vital factor for women micro-enterprise (Chirwa, 2008). Microentrepreneurs level of education was investigated predictor for enterprise performance because educated owner or manager can make decisions more efficiently as compared to others (Read, Song \& Smit, 2009). Therefore, education is an important contributor tomicro-enterprise success. According to Berry (1996), both general and special management education contributes to the success of the enterprise.

\subsection{Micro-Credit and Micro-Enterprise Success}

Literature provides the evidence that sufficient credit aids entrepreneurship performance (Gatewood et al., 2004; Lakwo, 2007; Martin, 1999; Olo, 2009). In result, credit provides assistance to entrepreneurs, especially women and it is often seen that it increases income, investment, output and welfare of entrepreneurs (Kuzilwa, 2005; Lakwo, 2007; Martin, 1999; Peter, 2001).

Credit has a positive impact on performance across the world. A research study in Kenya shows that credit has a positiveeffect on business performance (Peter, 2001). It also has a positive impact on income as well as the wellbeing of women in Uganda (Lakwo, 2007). In Nigeria, both credit and saving have positive consequences on performance (Olo, 2009). The positive impact of credit and training has also seen in Tanzania (Kuzilwa, 2005). Therefore, credit has significant positive linkage with micro-enterprise success. But economic performance mainly depends upon human capital which achieved through education (Streletzki and Schulte, 2013). 
Most of the studies show that micro-credit has a significant positive relationship with micro-enterprise (Copestake, Bhalotra, \& Johnson, 2001; Leach\&Sitaram, 2002). However, few studies show the question mark on the effectiveness of micro-credit (Cull, Demirgüç-Kunt, \& Morduch, 2009). It is due to the low level of education. As most of the poor people get credit and started micro-enterprise but due to not having enough educational level they cannot run efficiently. As literature proves that, most of the women from developing countries have a low educational level in term of poverty (Porter \&Nagarajan, 2005; Roomi\& Parrot, 2008). Therefore, due to low educational level, the effectiveness of micro-credit becomes limited. Thus, this study hypothesizes as follows:

Hypothesis 1: Micro-credit has significant positive relationship with micro-enterprise success Hypothesis 2: Education mediate the relationship between micro-credit and micro-enterprise success

\subsection{Micro-Training and Micro-Enterprise Success}

Entrepreneurship training need was first recognized in early 1990 (Ladzani and Van Vuuren, 2002). However, very little training offered, and it was confusion about small business training and entrepreneurship training (Nieman, 2000). After that with an increase in time training become the prominent tool to enhance micro-enterprise and adopted by microfinance institutions.

Failure in business is due to the lack of skills (Radipere and Van Scheers, 2005). Microfinance institution's clients are unable to use microfinance factors properly because they do not have uniqueabilities (Karnani, 2007). Business owners have responsibility for acquisition of skills, and they need to learn that how should they learn (Unger et al., 2009). Basically, training addresses the issues relating to small business such as problem-solving, business management, personnelmanagement and time constraint (Perks and Smith, 2008). Nurtures of skills depend upon entrepreneurial training, and it enhances the entrepreneurial performance (Nieman, 2000). Furthermore, generation of new ideas can be affected by training activity (DeTienne and Chandler, 2004). Therefore, training has significant positive linkage with micro-enterprise success. But education also acts side by side with training because formal education is mandatory for practical implementation.

Nevertheless, a certain amount of knowledge is required for success; it does not matter it comes from training or formal education (Aldrich and Martinez, 2001). Education and training have a positive influence on business success (Simpson, Tuck \& Bellamy, 2004). Entrepreneurship training is important to promote and enhance the performance of entrepreneurship (Glaub and Frese, 2011). Literature is showing the evidence that training has a positive influence on enterprise performance (Akanji, 2006; Cheston \& Kuhn, 2002; Kuzilwa, 2005). But the role of education is unforgettable, as microentrepreneurs level of education was investigated predictor for enterprise performance because educated owner or manager can make decisions more effectively as compared to others (Read, Song \& Smit, 2009). Thus, it is hypothesized that:

Hypothesis 3: Micro-training has significant positive relationship with micro-enterprise success Hypothesis 4: Education mediate the relationship between micro-training and micro-enterprise success

\section{Conclusion}

This study provides a conceptual relationship between micro-enterprise and microfinance services such as micro-credit and micro-training. It is investigated that, microfinance factors (i.e., micro-credit and microtraining) has a positive relationship with micro-enterprise success. However, among all other microfinance factors (i.e., micro-saving, micro-insurance, social capital), micro-credit and micro-training haverelatively higher effect on microenterprise performance followed by a level of education. It is found thateducation mediates the relation between microfinance factors and micro-enterprise success. By playing the role of mediator, education enhances the positive effect of micro-credit and micro-training on micro-enterprise success. Therefore, higher the level of education, higher would be the success of microenterprise and vice versa.

Provision of micro-credit after providing the micro-training to the owners or managers of micro-enterprise can be more beneficial for micro-enterprise success. But the role of education is crucial to get a maximum 
outcome from micro-credit and micro-training. Hence, a combination of micro-credit and micro-training with some degree of education is a real micro-enterprise success formula.

Future research is required for the better justification of results. This could be done by collecting data from respondents. Other microfinance factors such as micro-saving, micro-insurance and social capital can also be crucial for micro-enterprisesuccess. Therefore these elements can also be used in current framework for future research. Nevertheless, while reviewing the literature, it is observed that vulnerability has an influence on the relationship of microfinance services and micro-enterprise or women-empowerment. Hence, in future research environmental, social, political and economic vulnerability can be used as a moderator between microfinance factors and micro-enterprise success or women-empowerment. Additionally, the combined effect of three types of capital such as financial capital, human capital and social capital on women-empowerment through microfinance institutes is not examined in prior studies.

\section{References}

Adams, D. W., \& Von Pischke, J. D. (1992). Microenterprise credit programs: Déja vu. World Development, 20(10), 1463-1470.

Akanji, O. O. (2006). Microfinance as a strategy for poverty reduction. Central Bank of Nigeria Economic and Financial Review, 39 (4).

Aldrich, H.E. and Martinez, M.A. (2001). Many are called, but few are chosen: an evolutionary perspective for the study of entrepreneurship", Entrepreneurship: Theory and Practise, Vol. 25 No. Summer, pp. 41-55.

Alsbury, A. (2001). Quick answers to small business questions. Pearson Education.

Atmadja, A. S., Su, J. J., \& Sharma, P. (2016). Examining the impact of microfinance on microenterprise performance (implications for women-owned microenterprises in Indonesia). International Journal of Social Economics, 43(10), 962-981.

Baron, R. M., \& Kenny, D. A. (1986). The moderator-mediator variable distinction in social psychological research: Conceptual, strategic, and statistical considerations. Journal of personality and social psychology, 51(6), 1173.

Beaver, G. (2002). Small Business, Entrepreneurship and Enterprise Development. Pearson Education.

Bernard, D. K., Kevin, L. L. T., \& Khin, A. A. (2016). Entrepreneurial Success through Microfinance Services among Women Entrepreneurs in Sri Lanka: A Pilot Study and Overview of the Findings. International Journal of Economics and Financial Issues, 6(3).

Berry, M. (1996). Technical entrepreneurship, strategic awareness and corporate transformation in small high-tech firms. Technovation, 16(9), 487-522.

Cheston, S., \& Kuhn, L. (2002). Empowering women through microfinance. Draft, Opportunity International.

Chirwa, E.W. (2008). Effects of gender on the performance of micro and small enterprises in Malawi. Development Southern Africa, 25(3), 347-362.

Cooper, A. C., Gimeno-Gascon, F. J., \& Woo, C. Y. (1994). Initial human and financial capital as predictors of new venture performance. Journal of Business Venturing, 9(5), 371-395.

Copestake, J., Bhalotra, S., \& Johnson, S. (2001). Assessing the Impact of Microcredit: A Zambian Case Study. Journal of Development Studies, 37(4), 81-100.

Cull, R., Demirgüç-Kunt, A., \& Morduch, J. (2009). Microfinance Meets the Market. The Journal of Economic Perspectives, 23(1), 167-192.

DeTienne, D. R., \& Chandler, G. N. (2004). Opportunity identification and its role in the entrepreneurial classroom: A pedagogical approach and empirical test. Academy of Management Learning \& Education, 3(3), 242-257.

Fuente, A., \& Domenech, R. (2006). Human capital in growth regressions: How much difference does data quality make? Journal of the European Economic Association, 4(1), 1-36.

Gadenne, D. (1998). Critical success factors for small business: An inter-industry comparison. International Small Business Journal, 17(1), 36-56. 
Gatewood, E. J., Brush, C. G., Carter, N. M., Greene, P. G. \& Hart, M. M. (2004). Women entrepreneurs, growth and implications for the classroom. USA: Coleman Foundation whitepaper series for the USA Association for Small Business and Entrepreneurship.

Glaub, M., \& Frese, M. (2011). A critical review of the effects of entrepreneurship training in developing countries. Enterprise Development and Microfinance, 22(4), 335-353.

Harrison, R. T. \& Mason, C. M. (2007). Does gender matter? Women business angels and the supply of entrepreneurial finance. Entrepreneurship Theory and Practice, 31 (3), 445-472.

Ibru, C. (2009). Growing microfinance through new technologies. Federal University of Technology, Akure, Nigeria.

Imai, K. S., Arun, T., \& Annim, S. K. (2010). Microfinance and Household Poverty Reduction: New Evidence from India. World Development, 38(12), 1760-1774.

Karnani, A. (2007). Microfinance misses its mark. Retrieved February 18, 2009, from Standford Social Innovation Review:http://www.ssireview.org/articles.

Kuzilwa, J. (2005). The role of credit for small business success: A study of the National Entrepreneurship Development Fund in Tanzania. The Journal of Entrepreneurship, 14 (2), 131161.

Ladzani, W. M., \& Van Vuuren, J. J. (2002). Entrepreneurship training for emerging SMEs in South Africa. Journal of Small Business Management, 40(2), 154.

Lakwo, A. (2007). Microfinance, rural livelihood, and women's empowerment in Uganda. Retrieved August 3, 2009, from African Studies Center Research Report 2006: http://www.google.com

Lans, T., Hulsink, W. I. M., Baert, H., \& Mulder, M. (2008). Entrepreneurship education and training in a small business context: Insights from the competence-based approach. Journal of Enterprising Culture, 16(04), 363-383.

Leach, F., \& Sitaram, S. (2002). Microfinance and Women's Empowerment: A Lesson from India. Development in Practice, 12(5), 575-588.

Ledgerwood, J. (2000). Sustainable Banking with the poor. Microfinance Hand Book. An Institutional and Financial Perspective. The World Bank, Washington, D.C. 1-260

Magoutas, A.I., Papadogonas, T.A., \& Sfakianakis, G. (2012). Market structure, education and growth. International Journal of Business and Social Science, 3(12), 88-95.

Mamun, A. A. (2016). Access to Credit, Education and Entrepreneurial Competencies: A Study among Women Micro-entrepreneurs in Malaysia. Vision, 20(3), 159-168.

Martin, T. G. (1999). Socio-economic impact of microenterprise credit in the informal sector of Managua, Nicaragua. Retrieved January 21, 2009, from http://scholar.lib.vt.edu/thesis/

Naeem, A., Khan, S., Ali, M., \& Hassan, F. S. (2015). The Impact of Microfinance on Women MicroEnterprises “A Case Study of District Quetta, Pakistan". American International Journal of Social Science 4(4), 19-27.

Nieman, G. (2001). Training entrepreneurs and small business enterprises in South Africa: a situational analysis. Education+ Training, 43(8/9), 445-450.

Olu, O. J. O. (2009, November). Impact of microfinance on entrepreneurial development: The case of Nigeria. In The International Conference on Economics and Administration, Faculty of Administration and business (pp. 536-545).

Perks, S., \& Smith, E. E. (2008). Focused training programmes for solving growth problems of very small businesses. Acta Commercii, 8(1), 145-159.

Peter (2001). Impact of loan access on women-operated microenterprises in UASIN GISHU district, Eldoret, Kenya. In Alila and Pedersen (eds), 2001, Negotiating social space: East African microenterprises.

Porter, E. G. \& Nagarajan, K. V. (2005). Successful women entrepreneurs as pioneers: Results from a study conducted in Karaikudi, Tamil Nadu, India. Journal of Small Business and Entrepreneurship, 18 (1), 39-52.

Radipere, S., \& Van Scheers, L. (2005). Investigating whether a lack of marketing and managerial skills is the main cause of business failure in South Africa: management. South African Journal of economic and management sciences, 8(4), 402-411. 
Read, S., Song, M., \& Smit, W. (2009). A meta-analytic review of effectuation and venture performance. Journal of Business Venturing, 24(6), 573-587.

Robinson, M. (2001). The microfinance revolution: Sustainable finance for the poor. World Bank Publications.

Roomi, M. A. \& Parrot, G. (2008). Barriers to development and progression of women entrepreneurs in Pakistan. The Journal of Entrepreneurship, 17 (1), 59-72.

Simpson, M., Tuck, N., \& Bellamy, S. (2004). Small business success factors: the role of education and training. Education+ Training, 46(8/9), 481-491.

Streletzki, J.-G., \& Schulte, R. (2013). Start-up teams and venture capital exit performance in Germany: Venture capital firms are not selecting on the right criteria. Journal of Small Business \& Entrepreneurship, 26(6), 601-622.

Switzer, L., \& Huang, Y. (2007). How does human capital affect the performance of small and mid-cap mutual funds? Journal of Intellectual Capital, 8(4), 666-681.

Tazul, I. (2007). Microcredit and poverty alleviation. Hampshire, England: Ashgate Publishing Limited.

Unger, J. M., Keith, N., Hilling, C., Gielnik, M. M., \& Frese, M. (2009). Deliberate practice among South African small business owners: Relationships with education, cognitive ability, knowledge, and success. Journal of Occupational and Organizational Psychology, 82(1), 21-44. 